\section{Sustaining Public Plant Breeding to Meet Future National Needs}

\author{
James F. Hancock ${ }^{1}$ \\ Department of Horticulture, Michigan State University, 342 Plant and Soil \\ Sciences Building, East Lansing, MI 48824
}

Charles Stuber

CALS, Agricultural Research Service, North Carolina State University, Raleigh, NC 27695

A landmark workshop was held at North Carolina State University in Feb. 2007 to develop a national plant breeding coordinating committee and discuss the critical role that plant breeders play in the security of our nation's food and fiber resources. The workshop was organized by Ann Marie Thro, National Program Staff, USDA-CSREES, with the aid of a steering committee of plant breeders. Approximately 160 participants from all over the United States and many foreign countries attended the meeting, representing both the public (140) and private (20) sector.

The workshop was organized in response to concern about the steady decline in national plant breeding investment over the last 20 years, which has led to a significant reduction in the number of public plant breeders in the United States and a substantial weakening of university education programs. Several previous meetings have drawn attention to the decline in our nation's plant breeding capacity [National Plant Breeding Study (NPBS), 1994-96; 2001, http://www.csrees. usda.gov/nea/plants/part/pbgg_part_study.html; Seeds and Breeds 2003, 2005, http://savin gourseed.org/pdf/2003SeedsAndBreedsCon ference.pdf, http://www.agron.iastate.edu/ seedsandbreeds/; Plant Breeding Education Workshop, 2005 Michigan State University, HortScience 2006;41(1), http://hrt.msu.edu/ PBSymp/HancockSymposium.pdf], but their message was not nationally audible or sustained through the establishment of a permanent leadership group interested in maintaining plant breeding as a science and profession.

The new committee was established as a Land Grant University Multistate Project (SCC 080) and will actively work to raise awareness of what plant breeders have done for the nation and how they can contribute to the future vitality of the U.S. economy. The group will also seek to strengthen U.S. plant breeding capacity by encouraging improvements in infrastructure and education. The first slate of officers is: Stephen Baenziger at the University of Nebraska (Chair, pbaenziger1@ unl.edu), Philipp Simon, USDA-ARS at the

Received for publication 24 Aug. 2007. Accepted for publication 22 Oct. 2007.

${ }^{1}$ To whom reprint requests should be addressed; e-mail hancock@msu.edu
University of Wisconsin (Vice-chair, psimon@ wisc.edu), and Todd Wehner at North Carolina University (Secretary, todd_wehner@ ncsu.edu).

The overall tone for discussion at the meeting was set by a group of leading experts who presented talks on how plant breeding fits into six national goals: 1) excellence in science and technology (Stephen Baenziger and Fred Bliss); 2) a globally competitive agricultural system (Ronnie Coffman, Robert Herdt, and William Niebur); 3) competitiveness, sustainability, and quality of life in rural America (William Tracy, John Navazio, and Marcelo Carena); 4) a safe and secure food and biomaterials system (James Holland and Thomas Isleib); 5) a healthy well-nourished population (Linda Pollak and Philipp Simon); and 6) harmony between agriculture and environment (Charles Brummer and Stephen Jones). A review of these talks can be found in Stuber and Hancock (2007).

After the presentations, the participants broke into six subcommittees to discuss how plant breeders fit into each of the national goals described by the speakers. The groups were asked to answer three questions: 1) How can plant breeding support the goals? 2) What is needed to assemble a factual and compelling case? 3) What partnerships should plant breeding build with others? The groups were then directed to develop outlines of an action plan for the next $5 \mathrm{y}$ as well as a 2-y near-term plan, which they presented as preliminary outlines to the whole group at the end of the meeting. These action plans are to be completed in the coming year.

A number of common themes emerged out of the group deliberations. When discussing how plant breeding can support the six national goals outlined, most subcommittees stressed that maintaining the genetic diversity of our crops is paramount as plant breeders continue to develop well-adapted hybrids and varieties that are nutritious, productive, resistant to biotic and abiotic stresses, and have a place in a value-added economy. The group on "harmony between agriculture and the environment" stressed that plant breeders need to develop cultivars that combine well with sustainable management strategies to minimize negative impacts on the environment and positively affect the biosphere.

The subcommittee on a "healthy, wellnourished population" made the case that improved diet plays an important role in reducing the incidence of many healthrelated problems such as nutrient deficiencies, allergenicity, obesity, and diabetes. Plant breeders have contributed and will continue to contribute to improved diet by increasing health-promoting food properties (antioxidants, fiber, vitamins, and so on), decreasing unhealthy factors (allergens, unhealthy oils), altering the shelf life of food commodities, expanding where crops can be grown, improving the desirability of healthy foods (flavor, appearance, convenience), and reducing chemical input through increased pest resistance.

The subcommittee dealing with a "safe and secure food and fiber system" indicated that a key issue associated with our supply of energy is the increasing need to produce biofuels. The production of biofuels through the use of plant products provides cleaner, more environmentally friendly fuels and reduces our dependency on foreign oil. A potential consequence of increasing the use of plant products for biofuels is a reduction in their supply for food consumption. The group suggested that these concerns can be mitigated through the development of improved varieties of plants that produce more yield and biomass and resist more stresses.

It was repeated often by the subgroups that our nation must maintain an ample supply of well-trained plant breeders. The competitiveness of U.S. science depends on a continuous supply of innovative, well-educated, team-oriented plant breeders that can address complex research problems such as climate change, renewable energy, sustainability, diminishing per-capita natural resources, and improved human health. There needs to be a national priority focused on maintaining and strengthening university plant breeding and training programs in support of American agriculture, horticulture, and forestry science.

The "excellence in science" group stressed that plant breeding students must develop deep insight into a broad range of scientific endeavors, including the biological, genetic, and breeding behavior of crop species. Knowledge is needed on the individual species biology, genetics, germplasm, domesticated culture, variability to abiotic and biotic challenges, biology and genetics of symbionts and pathogens, their uses, and also the markets and industries into which they fit. The genetic advances of today in plant breeding are often based on experiments conducted years ago. Thus, people who become plant breeders must develop foresight that is years and even decades ahead of the crop germplasm base used in agriculture today.

When asked to describe what is needed to assemble a factual and compelling case for plant breeding, the most common observation among the subcommittees was that plant breeders need to more effectively communicate their numerous past successes and the potential for new successes, the key being to let community leaders and decision-makers know just what they have accomplished and 
what they can provide. It was suggested by many groups that plant breeders develop symposia at cross-science meetings like American Association for the Advancement of Science (AAAS) to more fully integrate plant breeding into the scientific community and raise awareness of its contributions. To this end, an AAAS symposium entitled "Crops for Health: Improving the Healthpromoting Properties of Food" that includes presentations by plant breeders and nutrition/ health researchers is scheduled for the 2008 AAAS meeting in Boston. A strong emphasis needs to be focused on forming an international society of plant breeders to put their interests at the fore.

The subcommittees were unanimous in their feeling that examples of plant breeding impacts need to be accumulated to create a compelling case for sustained efforts in plant breeding. These case studies should be distributed through a number of channels, including scientific review articles, press releases, symposia, and a web site that is attractive to students and the public at large. It was also felt that information about the role of plant breeders should be provided in pamphlet form to groups, including $\mathrm{K}-12,4-\mathrm{H}$, and Master Gardener programs.

It was pointed out by many groups that plant breeders must be more actively involved in providing input when priorities are set for CSREES-NRI programs and the national initiative on specialty crops. Plant breeders need to make themselves heard on the type of products that have sustainable value, and they need to have an opportunity to share in the resources provided to develop them. The group on "a safe and secure food and fiber system" suggested that there is a particular need to include economic analysis and benefits of plant breeding in revised NRC documentation written with involvement and input of the National Academy of Science breeders. A strong call was also made to strengthen the links between U.S. plant breeders and the CGIAR centers and international programs as a way to attract new international students to our programs and broaden the experiences of our domestic ones.

On the topic of what partnerships plant breeders need to build, several groups felt that it will be important to more fully integrate food and health professionals into breeding efforts. Plant breeders also need to engage consumer groups and local agricultural communities much earlier in the research and development pathway. The number of possible partnerships is large, ranging from governmental agencies at the federal and state levels to foundations and nongovernmental organizations.

There was a unified call for plant breeders to form partnerships with agricultural companies and organizations that successfully lobby policymakers such as the Farm Bureau, American Seed Trade Association, economic developmental councils, and commodity groups. The group on "harmony between agriculture and the environment" indicated that useful linkages could also be formed with the organic and sustainable farming communities and related groups such as the Seeds and Breeds Plant Breeding group, Organic Seed Alliance and Organic Seed Partnership, and environmental organizations such as Ducks Unlimited, the Audubon Society, and the Sierra Club.

The subcommittee on "harmony between agriculture and the environment" made the point that plant breeders need to develop or join interdisciplinary teams that include related biological, environmental, and social scientists; ecologists and farmers; nursery owners; and foresters. The selection system needs to be tailored to match ecologically sound production systems, not necessarily those in widespread use at the current time. The subcommittee on "healthy well-nourished population" indicated that partnerships should also be fostered with nutritionists, medical scientists, and health support groups.

The last order of business at the workshop was the election of a chair and secretary for each subcommittee. These individuals will serve as resources to the executive committee and make sure that the action plans of the various committees are fulfilled. These officers and their subcommittees were Excellence: David Stelly, Chair (Texas A \& M University) and Craig Yencho, Secretary (North Carolina State University); Global: Robert Bertram, Chair (USAID) and Jim McFerson, Secretary (Washington Tree Fruit Commission); Rural America: Marcelo Carena, Chair (North Dakota State University) and Keith Woeste, Secretary (USDA Forest Service, Purdue University); Nutrition/Healthy: Linda Pollak, Chair (USDAARS, Iowa State University) and Michael Havey, Secretary (USDA-ARS, University of Wisconsin); Environmental: Charlie Brummer, Chair (University of Georgia) and Richard Pratt, Secretary (Ohio State Univer- sity); and Safe and Secure Food: Travis Frey, Chair (Monsanto Inc.) and James Holland, Secretary (North Carolina State University). Emphasizing the importance of education, a new subcommittee for education was also established by the executive group, which will be chaired by Tom Stalker (North Carolina University) with David Knauft as Secretary (University of Georgia). Education was deemed critical to the future supply of plant breeders.

In addition to these officers, liaisons were elected to a number of professional groups, including Ronnie Coffman, Cornell University (international plant breeding centers); Bill Tracy, University of Wisconsin (private nonprofit breeders); Steve McKeand, North Carolina State University (forestry plant breeders); Herb Ohm, Purdue University (CSSA plant breeders); Linda Wessel-Beaver, University of Puerto Rico (ASHS plant breeders), Kay Simmons (USDA-ARS, Beltsville, MD), and Greg Tolla, Seminis Vegetable Seeds (NCCPB). Mark Hussey, Texas A \& M University, will be the Administrative Advisor of the Committee and Ann Marie Thro will be the CSREES representative.

The next meeting of the Plant Breeding Coordinating Committee will be hosted by Monsanto in Ankeny, IA, on June 16 to 18 , 2008. Specific needs that will be addressed at this workshop will be: 1) the need to partner and communicate effectively with other sectors of our society about the value of plant breeding to broad national goals shared by all; and 2) the need to communicate effectively with research directors and managers about quality of plant breeding programs. Invited speakers will be asked to participate in exploratory discussions about contributions, interfaces, and potential joint actions between their sector and plant breeding. A specialist in research evaluation will be identified to help the group identify ways to describe relative performance of plant breeding programs.

To get more information about SCC- 80 and the details of the various subcommittee road maps, consult the Global Plant Breeding web site at http://cuke.hort.ncsu.edu/gpb/ index.html

\section{Literature Cited}

Stuber, C. and J. Hancock. 2007. Sustaining plant breeding-Report on national workshop. Crop Sci. (in press). 